\title{
Cost-effectiveness of a cardiovascular disease primary prevention programme in a primary health care setting. Results of the Polish part of the EUROACTION project
}

\author{
Nevena Šović1 ${ }^{1}$ Andrzej Pająk ${ }^{1}$, Piotr Jankowski², Alejandra Duenas³ ${ }^{3}$ Kalina Kawecka-Jaszcz², \\ Renata Wolfshaut-Wolak ${ }^{1}$, Urszula Stepaniak ${ }^{1}$, Paweł Kawalec ${ }^{1}$ \\ IInstitute of Public Health, Faculty of Health Sciences, Jagiellonian University Collegium Medicum, Krakow, Poland \\ $21^{\text {st }}$ Department of Cardiology and Hypertension, Jagiellonian University Collegium Medicum, Krakow, Poland \\ ${ }^{3}$ IESEG School of Management (LEM-CNRS, HEMO), Paris, France
}

\begin{abstract}
A b stract
Background: Well designed cardiovascular disease (CVD) prevention programmes appear to be generally applicable and effective in reducing exposure to risk factors and the incidence of disease. However, introducing them broadly into clinical practice would have a significant impact on the healthcare budget, and requires careful consideration.

Aim: The purpose of this health economic analysis was to assess the potential cost-effectiveness of the model nurse-led, comprehensive CVD primary prevention programme which was prepared and introduced in the EUROACTION project, in high-risk patients in Poland.

Methods: A Markov model was developed to assess the long-term costs of preventive intervention. The health states modelled were: event-free (all patients at the beginning of observation), stable angina first year, acute myocardial infarction, stable angina subsequent year, myocardial infarction subsequent year, CVD death, and other causes of death. Health benefits from the reduction in risk factors were estimated based on Framingham risk function assuming the probability of defined health states according to British registers. The time horizon of the analysis was ten years, and one Markov cycle length was one year. The analysis was prepared from the healthcare payer's perspective. A willingness to pay threshold of three gross domestic product (GDP) per capita / quality-adjusted life years (QALY) was used. Univariate sensitivity analysis was conducted. Results were presented as an incremental cost-effectiveness ratio (ICER) expressed as an incremental cost per QALY.

Results: In Poland, EUROACTION intervention resulted mainly in reductions in the prevalence of smoking (by $14 \%$ ) and high blood pressure (by 7\%). Intervention on other risk factors, including blood lipids, was found to be less effective. Estimated ICERs were 19,524 PLN for men and 82,262 PLN for women. The programme was even more cost-effective in smokers i.e. estimated ICERs were 12,377 PLN in men and 53,471 PLN in women. The results were most sensitive to variations in health states utilities and cost value range as well as the duration of treatment effect.

Conclusions: The model nurse-led, comprehensive CVD primary prevention programme developed in the EUROACTION project appears to be potentially highly cost-effective for high-risk male patients in Poland (below 1 GDP per capita per QALY). For women, the cost-effectiveness was less but still below the acceptable threshold (below three GDP per capita per QALY), although the sensitivity analysis showed that results were a subject of some uncertainty.
\end{abstract}

Key words: cardiovascular disease, primary prevention, EUROACTION project, cost-effectiveness

Kardiol Pol 2013; 71, 7: 702-711

\section{Address for correspondence:}

Paweł Kawalec, MD, PhD, Institute of Public Health, Faculty of Health Sciences, Jagiellonian University Collegium Medicum, ul. Grzegorzecka 20, $31-531$ Kraków, Poland, e-mail: mxpkawal@cyf-kr.edu.pl

Received: 24.05.2012 Accepted: 19.03.2013

Copyright (C) Polskie Towarzystwo Kardiologiczne 


\section{INTRODUCTION}

Mortality due to coronary heart disease (CHD) has been decreasing in Poland since 1991 [1]. However, the prevalence of $\mathrm{CHD}$ is still high, due to prolonged life expectancy and longer survival after CHD events. From the economic perspective, $\mathrm{CHD}$ imposes a great cost for the National Health Fund (NHF) and Polish society. In 2005, the total cost of CHD in Poland was estimated to be $€ 2,056.7$ million [2]. Evidently, there is a clinical and economic imperative to develop effective strategies in order to reduce the total burden of $\mathrm{CHD}$.

The recent study of primary prevention in Poland showed that the effectiveness of the routine management of risk factors in usual care is low [3]. The National Programme of Cardiovascular Disease Prevention, introduced by NHF, appeared to be effective in identifying high-risk patients, but far less effective in risk factor control. The final conclusion of this study, which was carried out within the framework of the POLKARD project of the Polish Ministry of Health, was that there is an urgent need to introduce an effective and structured intervention on risk factors [3].

Preventive intervention is widely recognised as an effective way to reduce the incidence and progression of CHD. Nonetheless, there have been only a few attempts at controlled intervention on risk factors in Poland. Recently, Poland has taken part in the EUROACTION project, an international initiative demonstrating that control of risk factors, lifestyle changes and therapeutic goals defined in the guidelines for cardiovascular prevention are achievable in everyday clinical practice $[4,5]$. The methods of intervention applied in the EUROACTION project could serve as a model solution. However, the cost-effectiveness of such an intervention is not known. And to date there has been no analysis on the cost-effectiveness of prevention programmes in Poland.

The purpose of this study was therefore to assess the potential cost-effectiveness of a nurse-led, comprehensive cardiovascular disease (CVD) primary prevention programme which was prepared and introduced as part of the EUROACTION project involving high-risk patients in Poland.

\section{METHODS}

This analysis concerned the Polish component of the primary care of the EUROACTION project which was conducted between 2003 and 2006 in eight European countries.

The main objective of the project was to help people at high risk of $\mathrm{CHD}$ to achieve the recommended lifestyle, to increase compliance with cardioprotective medication, to improve the control of risk factors, and to help reach therapeutic goals for CHD prevention. The project was a cluster randomised clinical trial and the intervention programme consisted of a one-year comprehensive preventive intervention co-ordinated by specially trained nurses. Patients from both groups (intervention and usual care) were invited for reassessment after one year $[4,5]$. Health benefits of the intervention

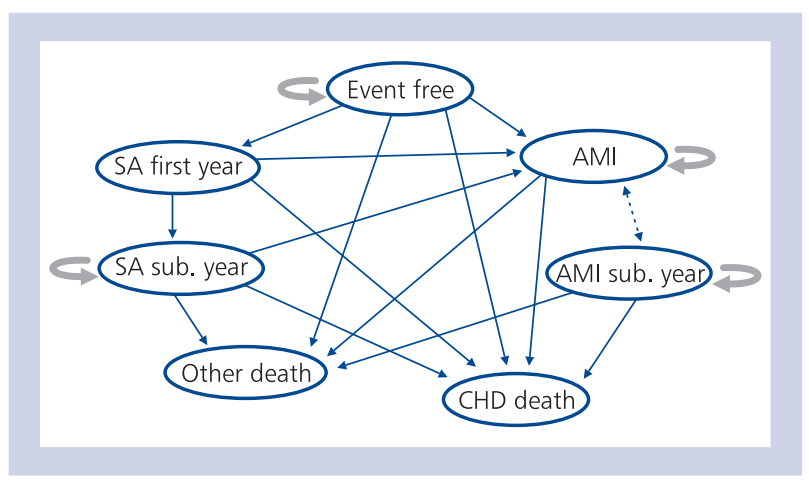

Figure 1. Structure of Markov model; SA — stable angina; SA sub. year - stable angina subsequent year; CHD — coronary heart disease; AMI - acute myocardial infarction; AMI sub. year - acute myocardial infarction subsequent year

for this analysis were assessed using the percentage of changes in risk factor levels observed in patients taking part in the Polish EUROACTION study in combination with the Framingham risk function to predict the reduction in cardiovascular events [6]. In order to assess the long term costs and health benefits of the EUROACTION-model intervention, a Markov model was developed assuming that changes in risk profiles of patients as surrogate outcomes recorded in the trial would result in a corresponding change in clinical outcomes and that the immediate effects of the intervention would persist over the following ten years (Fig. 1). The analysis was done from the health insurer's perspective. The cycle length was one year. The main outcome measure modelled was quality-adjusted life years (QALY) gained. Results were presented in terms of the incremental cost-effectiveness ratio (ICER) which determines the additional cost of introducing intervention per QALY gained compared to usual care. The ICER was calculated as the difference in costs divided by the difference in effectiveness expressed in QALY. The cost-effectiveness threshold was set at the level of $3 \times$ gross domestic product (GDP) per capita according to the previously accepted recommendation of the World Health Organisation Commission on Macroeconomics and Health (www. who.int/choice/costs/CER_thresholds/en/index.html [cited 2010 Mar 30]), which gave the value of the threshold in Poland at time of analysis as 99,543 PLN per QALY gained (for GDP 33.181 PLN, www.stat.gov.pl/cps/rde/xbcr/gus/PUBL_f_poland_in_figures_2009.pdf [cited 2010 Mar 3]). Following the recommendation of the Polish Agency for Health Technology Assessment (AHTA-Pol), discount rates of 5\% and 3.5\% were applied to costs and health benefits respectively (AHTA-Pol, 2009; www.aotm.gov.pl [cited 2010 Apr 2]). Half cycle correction was applied. Univariate sensitivity analysis was conducted. Wherever possible, Polish-specific data was used; if not available, the best evidence from other settings was used.

The model included two hypothetical cohorts of 1,000 people at high risk of $\mathrm{CHD}$ for ten years after they were 
involved in one-year intervention or monitored in usual care. It was assumed that, during the intervention, changes in risk factor levels were the same as observed in the EUROACTION study.

The immediate effects of the intervention resulted in lower absolute risk of a primary $\mathrm{CHD}$ event in the intervention cohort at the beginning of the Markov model. CHD was defined as the onset of stable angina (SA), a non-fatal myocardial infarction (MI) and death from CHD-related causes. The health states modelled were: event-free, SA first year, acute myocardial infarction (AMI), SA subsequent year, MI subsequent year, CHD death, and other causes of death. It was assumed that all patients entered the Markov model in an event-free health state and that every third AMI was fatal (Fig. 1). To determine distribution to specific CHD events, in the absence of published Polish data, age- and gender-dependent incidence rates of primary events and transition probabilities of secondary events were derived from British registries [7]. The probability of transition from SA to AMI and CHD death was calculated using constant rate $(\mathrm{SA}$ to $\mathrm{AMI}=0.011$, and $\mathrm{SA}$ to $\mathrm{CHD}$ death $=0.007$ at the age of 67 years), in combination with changes in incidence rates to calculate probabilities by age. The transition probabilities from non-fatal AMI, and MI subsequent year to secondary AMI or CHD death were taken directly from Ward et al. [7]. The probability of dying from non-CHD causes was derived from Life Tables (http://www.stat.gov.pl/gus/5840_894_ENG_HTML.htm [cited 2009 Dec 20]), adjusted for the age-specific mortality due to $\mathrm{CHD}$, reported in the official national mortality statistics [8]. All costs were estimated according to the real costs of the EUROACTION project from 2010 and expressed in Polish zloty (PLN). The cost of the intervention programme was calculated excluding the costs related to the research part of the EUROACTION project. Average cost per patient was calculated by totalling all costs in the intervention year and dividing by the number of patients. Total costs included: pre-intervention cost, programme delivery cost, cost of final assessment, and cost of pharmacological treatment. The pre-intervention cost included: cost of training for nurses, time needed for eligibility assessment from medical records, costs of invitation, and cost of baseline assessment (nurse's time - on average 45 min per patient, 'Smokerlyzer', questionnaires and laboratory tests). Baseline screening included: assessment of lifestyle, medical history, use of medications, measurements of blood pressure, waist circumference, height and weight, and blood collection for the determination of blood lipids and glucose concentration. Programme delivery costs included: the time of the health professionals, phone calls, printed materials, and laboratory tests. Cost of final assessment included: invitation phone calls, the nurse's time (on average 30 min per patient), questionnaires and laboratory tests. Average salaries of health professionals were taken from publications of the Central Statistical Office of Poland (http:// www.stat.gov.pl/english/gus/praca_ludnosc [cited 2010 Feb 6]) and inflated to the present day using the Consumer Price Index (http://www.stat.gov.pl/gus/5840_7507_ENG_HTML.htm [cited
Table 1. Cost of the intervention programme without medications

\begin{tabular}{|lccc|} 
Cost category & & $\begin{array}{c}\text { Price per } \\
\text { unit (PLN) }\end{array}$ & $\begin{array}{c}\text { Total } \\
\text { (PLN) }\end{array}$ \\
\hline Training for nurses & & & $2,360.00$ \\
Equipment & & & $2,000.00$ \\
Nurse's time [h] & 924.2 & 17.20 & $15,896.24$ \\
GP's time [h] & 148 & 27.00 & $3,996.00$ \\
Phone calls [min] & 7,660 & 0.19 & $1,455.40$ \\
Questionnaires & 466 & 1.00 & 466.00 \\
Blood glucose tests & 634 & 8.00 & $5,072.00$ \\
Blood lipids tests & 930 & 24.00 & $22,320.00$ \\
Printed materials [set] & 233 & 8.10 & $1,887.30$ \\
Total & & & $55,452.94$ \\
Cost per patient & & & 238.00 \\
\hline
\end{tabular}

GP — general practitioner

Table 2. Summary of costs

\begin{tabular}{|lc|}
\hline Cost category & PLN (2010) \\
\hline Intervention group (medication included) & 329.00 \\
Usual care group (intervention year) & 116.70 \\
Stable angina, first year & $1,295.00$ \\
Stable angina, subsequent year & 697.00 \\
Acute myocardial infarction & $8,613.00$ \\
Myocardial infarction, subsequent year & 697.00 \\
Coronary heart disease death & $2,911.00$ \\
Other causes of death & 0.00 \\
Event free state, usual care, post-intervention years & 116.70 \\
Event free state, intervention group, & 135.00 \\
post-intervention years & \\
\hline
\end{tabular}

2010 Feb 6]). For the costs of laboratory assays, laboratories from different regions of Poland were contacted and finally the average prices from four laboratories serving a large numbers of patients were accepted. The price of telephone calls was taken from the website of the main Polish telephone provider (TP SA). The prices of printed materials were provided from a local printing company based on a sample of the EUROACTION materials. The price of the Smokerlyzer was obtained from the official Bedfont distributor for Poland. The cost of training was calculated based on current practices and prices of training for health professionals in Krakow (Table 1). The cost of pharmacotherapy was calculated from patients' individual data, taking into account medication type and recommended daily dose. It was assumed that lifestyle changes were initiated in all patientsat the beginning of the intervention. If those changes were not sufficient within the first two months, patients were prescribed more intensive therapy. The total annual cost of intervention was estimated at 329.00 PLN per patient (Table 2). The cost of usual 
Table 3. In-hospital treatment of patients with acute myocardial infarction

\begin{tabular}{|c|c|c|c|c|c|}
\hline Type of treatment & $\begin{array}{l}\text { DRG } \\
\text { group }\end{array}$ & $\begin{array}{c}\text { Proportion } \\
\text { of NSTEMI } \\
\text { patients }\end{array}$ & $\begin{array}{c}\text { Proportion } \\
\text { of STEMI } \\
\text { patients }\end{array}$ & $\begin{array}{c}\text { Points } \\
\text { NSTEMI }\end{array}$ & $\begin{array}{l}\text { Points } \\
\text { STEMI }\end{array}$ \\
\hline Thrombolysis performed as the only reperfusion therapy & E19 & 0.006 & 0.078 & 135 & 135 \\
\hline Glycoprotein IIb/lllb inhibitor & & 0.031 & 0.159 & 63 & 63 \\
\hline Coronary angiography performed but without subsequent PCI & E27 & 0.086 & 0.037 & 32 & 32 \\
\hline $\mathrm{PCl}$ as a complex treatment (angiography, thrombolysis, stents) & E12 & 0.231 & 0.555 & 265 & 265 \\
\hline CABG & E06 & 0.056 & 0.045 & 384 & 384 \\
\hline \multicolumn{6}{|l|}{ Treatment without revascularisation } \\
\hline NSTEMI & E18 & 0.621 & & 30 & \\
\hline STEMI & E17 & & 0.285 & & 37 \\
\hline
\end{tabular}

DRG — diagnosis related groups; STEMI — ST elevation myocardial infarction; NSTEMI — non-ST elevation myocardial infarction; PCI — percutaneous coronary intervention; CABG — coronary artery bypass grafting

care during the intervention year was calculated assuming that high-risk people under usual care have at least one doctor's consultation and one set of blood tests per year. It was also assumed that patients in the usual care cohort did not have any change in therapy during the intervention year.

The cost of the usual care was calculated at 116.70 PLN per patient (Table 2). The cost of event-free health state in the following years was calculated assuming that patients in both cohorts had the same frequency of attending general practice after the intervention year (a minimum of one doctor's consultation and one blood test per year), but that the difference in pharmacotherapy costs persists over time, regardless of any future changes. The cost of event-free health state was calculated as 116.70 PLN in usual care and 135.00 PLN in the intervention cohort. The annual cost of SA was derived from the study on costs related to diagnostics and treatment of coronary artery disease in Poland on an outpatient basis [2]. The average cost was calculated by totalling the reported annual costs of a doctor's consultations, laboratory tests and medications. The cost of diagnostic treatment was included in the cost of SA in the first year only, assuming that regular monitoring would be sufficient in subsequent years. This calculation gave the amount of 1,295.00 PLN (per patient per annum) for the first year SA and 697.00 PLN for SA subsequent year. In this analysis, an attempt was made to estimate the average cost of AMI from data on current system of payment for services to healthcare providers in Poland and data from the Polish Registry of Acute Coronary Syndromes (PL-ACS) [9]. All cases of AMI were classified in several diagnosis related groups (DRG) (Table 3), to which the costs of in-hospital pharmacotherapy were already assigned. The cost after discharge was assumed to be the same for SA subsequent year. Applying a point value for 2010 (51.00 PLN), and the proportions of patients having ST elevation myocardial infarction (STEMI; 0.54) and non-STEMI (0.46) [9], the average annual cost of AMI per patient was calculated as 8,613.00 PLN. The cost of $\mathrm{MI}$ subsequent year was assumed to be the same for SA subsequent year, 697.00 PLN. The cost of CHD death was calculated based on estimates that $50 \%$ of CHD deaths are sudden cardiac deaths [10] and that $40 \%$ of those deaths occur without witnesses and therefore without chances for resuscitation [11]. For the purpose of the analysis, it was assumed that $20 \%$ of CHD deaths happened without any contact with healthcare professionals; to account for the proportion of patients who die before emergency care reaches them, it was assumed that the remaining $80 \%$ of deaths generated the cost of fatal MI without revascularisation. The cost of $\mathrm{CHD}$ death was calculated as 2,911.00 PLN. A summary of all costs is presented in Table 2. As health-related quality of life (HRQoL) in the general population normally decreases with age, a linear correlation [7] derived from data on the UK general population [12] was used to adjust utility of event-free state by age: utility by age $=1.06-0.004 \times$ age. Utility weights for the first year health states were taken from relevant studies [13, 14]. To account for an increase in HRQoL among patients with CHD over time, especially among those who underwent revascularisation and cardiac rehabilitation, higher utility weights were assigned to the health states in subsequent years suggested in previously published cost-effectiveness studies [15-18]. For the secondary event, it was assumed that a patient had an additional reduction in utility weight of 10\% [15]. The first Polish general utility values derived from the EQ-5D questionnaire were published in 2010 [19, 20], expressed as a mean value for each age group in ten yearintervals [19]. Although the authors stated several weaknesses of their study (small sample size and questionable representativeness of the sample), those values were included in sensitivity analysis as utility values of the event-free health state by age. A summary of all utility weights used in analysis is presented in Table 4.

Base case analysis considered the cost-effectiveness of the intervention offered to men and women who were 57 years old, with the average baseline risk profile of Polish 
Table 4. Utilities used in analysis

\begin{tabular}{|lcc|}
\hline Health state & Utility weight & Source \\
\hline Stable angina, first year & 0.8 & {$[14]$} \\
Acute myocardial infarction & 0.7 & {$[13,15]$} \\
Stable angina, subsequent year & 0.9 & {$[15,17,18]$} \\
Myocardial infarction, & 0.8 & {$[15,16]$} \\
subsequent year & & \\
Utility of event-free state by age $=$ & $1.06-0.004$ & {$[7,12]$} \\
& $\times$ age & \\
Polish-specific utility values for event-free & \\
state by age used in sensitivity analysis & \\
Age group 45-54 & 0.9 & \\
Age group 55-64 & 0.894 & {$[19,20]$} \\
Age group $\geq 65$ & 0.798 &
\end{tabular}

patients involved in the EUROACTION study (systolic blood pressure $=141.09 \mathrm{~mm} \mathrm{Hg}$, total cholesterol $=6.05 \mathrm{mmol} / \mathrm{L}$, $\mathrm{HDL}=1.56 \mathrm{mmol} / \mathrm{L}$ ) and without additional risk factors, who achieved mean percentage reduction in risk factor levels. As many EUROACTION patients were smokers at baseline, one analysis was done adding smoking as a risk factor to the average risk profile.

\section{RESULTS}

In the Polish component of the EUROACTION project, in the intervention general practice, 278 eligible patients were identified, of whom 256 attended baseline screening and 233 had a full final assessment. In usual care practice, 320 eligible patients were identified and a random sub-sample of 80 patients were invited for a baseline screening, of whom 44 participated in baseline screening; 28 of those 44 participated in a one year follow-up. An additional 133 patients in usual care practice underwent only the final assessment. Data on 233 patients from the intervention clinic and 28 patients from the usual care for whom complete information was available at the end of the one-year follow-up period was used in the present study. Descriptive statistics for risk factors and treatments in the intervention and usual care groups are given in Table 5. In the intervention group, pharmacotherapy was initiated in $8.15 \%$ of previously untreated patients. There was an increase in the prescription of angiotensin-converting enzyme inhibitors, statins and diuretics. In the usual care group, there were no significant changes in therapy. The proportion of patients who reached the treatment target for blood pressure increased to $72.5 \%$ in the intervention group and to $50 \%$ in the usual care group (relative change was $28 \%, 95 \% \mathrm{Cl} 14.7-41.2$ ). The proportion of patients who achieved the treatment target for total cholesterol in the intervention group increased to $22.7 \%$, but the increase in the usual care group was similar and the relative change was not significant $(0.004,95 \% \mathrm{Cl}-13.7$ to 14.5$)$.
Table 5. Baseline assessment of patients enrolled in Polish primary care of the EUROACTION project

\begin{tabular}{|lcc|}
\hline & Intervention & Usual care \\
\hline Age [years] & $56.5 \pm 5.8$ & $57.0 \pm 6.9$ \\
Male & $96(41 \%)$ & $16(57 \%)$ \\
$\mathrm{SBP}[\mathrm{mm} \mathrm{Hg}]$ & $141.1 \pm 17.2$ & $139.9 \pm 12.7$ \\
$\mathrm{TC}[\mathrm{mmol} / \mathrm{L}]$ & $6.05 \pm 0.97$ & $5.42 \pm 0.69$ \\
$\mathrm{HDL}-\mathrm{C}[\mathrm{mmol} / \mathrm{L}]$ & $1.56 \pm 0.39$ & $1.49 \pm 0.37)$ \\
Current smokers & $103(44.2 \%)$ & $9(32.1 \%)$ \\
Diabetics & $27(11.6 \%)$ & $3(10.7 \%)$ \\
BP $<140 / 90 \mathrm{~mm} \mathrm{Hg}$, and & $87(37.3 \%)$ & $12(42.9 \%)$ \\
$<130 / 85 \mathrm{~mm} \mathrm{Hg}$ in diabetics & & \\
TC $<5 \mathrm{mmol} / \mathrm{L}$ & $27(11.6 \%)$ & $8(28.6 \%)$ \\
Cardioprotective drugs & $132(56.7 \%)$ & $19(67.9 \%)$ \\
Beta-blockers & $55(23.6 \%)$ & $4(14.3 \%)$ \\
ACEl & $89(38 \%)$ & $10(35.7 \%)$ \\
Statins & $48(20.6 \%)$ & $5(17.9 \%)$ \\
\hline
\end{tabular}

SBP — systolic blood pressure; TC - total cholesterol, HDL-C - high density lipoprotein cholesterol; ACEI — angiotensin converting enzyme inhibitors; BP — blood pressure

EUROACTION intervention resulted mainly in a reduction of the prevalence of smoking (by 14\%) and of high blood pressure (by $7 \%$ on average). In contrast to men, women achieved a decrease in total cholesterol concentration, but a greater decrease in HDL-cholesterol was observed as well. Reduction in cardiovascular risk factors (as a percentage of change from baseline) is presented by sex in Table 6 . The model estimated that over the period of ten years, a cohort of people who would undergo the intervention programme would gain greater health benefits compared to a cohort of people under usual care, but that this would increase the cost for NHF. After applying discount rates, an estimated ICER was 19,524 PLN for men and 82,262 PLN for women (Table 7). For smokers, the cost-effectiveness was even higher as discounted ICERs were 12,377 PLN for men and 53,471 PLN for women (Table 7). The results of the univariate sensitivity analyses are presented in Table 8. The model displayed the highest sensitivity to changes of health states utilities and duration of intervention effects. In women, if the effect of the intervention lasts shorter than the assumed ten years, the intervention would probably exceed the cost effectiveness threshold. For example, for five years the cost for QALY would be twice as high as the threshold value of three GDPs.

\section{DISCUSSION}

Our analysis shows that despite a relatively small effect on risk factors, offering the EUROACTION model intervention to patients at high risk of $\mathrm{CHD}$ in Poland would yield potentially an extra quality-adjusted year of survival at a cost of QALY for less than one GDP per capita $(33,181$ PLN) for men. Results 
Table 6. Change in the main cardiovascular disease risk factors

\begin{tabular}{lccccc|} 
Patients & Number & \multicolumn{3}{c|}{ Percentage of change from baseline level } \\
\cline { 2 - 5 } & & $\begin{array}{c}\text { Systolic blood } \\
\text { pressure }\end{array}$ & $\begin{array}{c}\text { Total } \\
\text { cholesterol }\end{array}$ & $\begin{array}{c}\text { HDL } \\
\text { cholesterol }\end{array}$ & $\begin{array}{c}\text { Quitted smoking } \\
\text { (\% of smokers) }\end{array}$ \\
\hline Men & 96 & -7.37 & -4.53 & -4.48 & 11 \\
Intervention & 16 & 0.22 & -4.46 & -4.22 & 0 \\
Usual care & & & & -18.13 & 15.5 \\
Women & 137 & -7.44 & -6.32 & -15.00 & 0 \\
Intervention & 12 & -4.95 & -1.46 & & \\
Usual care & & & & & \\
\hline
\end{tabular}

Table 7. Results of the base case analysis: incremental costs and QALYs for cohorts of 1,000 patients, 57 years old, profile $\mathrm{SBP}=141.09 ; \mathrm{TC}=6.05 \mathrm{mmol} / \mathrm{L} ; \mathrm{HDL}-\mathrm{C}=1.57 \mathrm{~mol} / \mathrm{L}$ non smokers, and smokers

\begin{tabular}{|c|c|c|c|c|c|c|}
\hline & \multicolumn{3}{|c|}{ Undiscounted } & \multicolumn{3}{|c|}{ Discounted } \\
\hline & $\begin{array}{l}\text { Incremental } \\
\text { costs (PLN) }\end{array}$ & $\begin{array}{c}\text { Incremental } \\
\text { QALYs }\end{array}$ & $\begin{array}{l}\text { ICER } \\
\text { (PLN) }\end{array}$ & $\begin{array}{l}\text { Incremental } \\
\text { costs (PLN) }\end{array}$ & $\begin{array}{c}\text { Incremental } \\
\text { QALYs }\end{array}$ & $\begin{array}{l}\text { ICER } \\
\text { (PLN) }\end{array}$ \\
\hline Men (ns) & $259,171.04$ & 16.61 & $15,600.81$ & $255,163.79$ & 13.07 & $19,523.91$ \\
\hline Women (ns) & $347,492.35$ & 4.95 & $70,236.64$ & $319,289.12$ & 3.88 & $82,261.84$ \\
\hline Men (s) & $213,829.02$ & 22.77 & $9,390.02$ & $221,990.86$ & 17.94 & $12,377.28$ \\
\hline Women (s) & $327,155.19$ & 7.26 & $45,071.11$ & $304,602.39$ & 5.70 & $53,470.97$ \\
\hline
\end{tabular}

SBP — systolic blood pressure; TC — total cholesterol; HDL-C — high density lipoprotein cholesterol; PLN — New Polish zloty (2010 values); ICER — incremental cost per quality-adjusted life years (QALY); ns — non smokers; s — smokers

for women were significantly higher, but the majority of them were still below the acceptable threshold of three GDP per capita, and they should be interpreted with more caution as results derived under the assumption that utility weights of the health states are $10 \%$ higher than in the base case analysis and that the intervention effect lasts for five years, exceeding the suggested threshold. Costs of a QALY were lower in smokers and in older people, thus confirming that cost-effectiveness increased with higher baseline absolute risk.

The estimated ICERs differed significantly between men and women at the same age, which was to be expected considering that the absolute risk of CHD and consequently the amount of QALYs gained by introducing the intervention, was much higher for men than for women.

A relatively small number of published studies have addressed the cost-effectiveness of multifactorial interventions for prevention in usual care, and there have been many differences among them in terms of intervention type, settings, sample populations, perspective and economic methods employed. The design and objective of EUROACTION differed significantly from all interventions evaluated previously and comparisons are not straightforward.

Sensitivity analysis showed that if the results of intervention are the same as the EUROACTION average, cost-effectiveness would be even higher compared to the total EUROACTION study group, Polish patients were younger and the proportion of females was higher. At baseline assessment, they had higher mean total cholesterol level and the proportion of smokers was higher than in the overall EUROACTION study group. A lower proportion of patients in Poland was classified as diabetics. The one-year follow-up assessment showed that Polish patients achieved greater decreases in systolic blood pressure than the whole EUROACTION study group ( -10 vs. $-7.6 \mathrm{~mm} \mathrm{Hg}$ ), a similar decrease in total cholesterol although from a higher baseline level, and 14 out of 103 (13.6\%) smokers at baseline quitted smoking. Polish patients showed a definite decrease in blood HDL-cholesterol [4, 5].

Interpretating these results must be carried out with caution. The effectiveness of the intervention was estimated based on the difference in the reduction of risk factors between the intervention group and the usual care group. There is some uncertainty about the transferability of risk factors changes into reductions in CHD events. Future studies, with a larger sample size and longer follow-up in order to capture clinical outcomes, are essential to validate the number of events predicted by this model. Furthermore, our control group was very small, and the presence of outliers could have changed the estimation of effectiveness significantly. The model was also based on the assumption that the effect of intervention persisted over ten years. Some previous studies have shown that the effects of less intensive interventions have been sustained over at least three or six years [21, 22], however, the 
Table 8. Summary of the results of the univariate sensitivity analyses for cohorts of men and women, 57 years old, with the average risk profile: $\mathrm{SBP}=141.09, \mathrm{TC}=6.05 \mathrm{mmol} / \mathrm{L}, \mathrm{HDL}-\mathrm{C}=1.57 \mathrm{mmol} / \mathrm{L}$ discounted incremental cost per QALY, (PLN)

\begin{tabular}{|c|c|c|c|}
\hline \multirow[t]{2}{*}{ VALUE } & & \multicolumn{2}{|c|}{ ICER (PLN) } \\
\hline & & Men & Women \\
\hline \multicolumn{4}{|l|}{ Base case } \\
\hline \multicolumn{2}{|l|}{ (discount rates $5 \%$ for costs, $3.5 \%$ for utilities) } & $19,523.91$ & $82,261.84$ \\
\hline \multicolumn{4}{|l|}{ Sensitivity analysis } \\
\hline \multirow[t]{3}{*}{ Discount rates } & $0 \%$ for costs and utilities & $15,600.81$ & $70,236.64$ \\
\hline & $5 \%$ for costs and utilities & $21,539.32$ & $90,857.46$ \\
\hline & $5 \%$ for costs. $0 \%$ for utilities & $15,359.59$ & $64,536.08$ \\
\hline \multicolumn{4}{|l|}{ Costs } \\
\hline \multirow[t]{2}{*}{ Cost of intervention (no change in medication) } & plus $20 \%$ & $23,120.12$ & $94,370.95$ \\
\hline & minus $20 \%$ & $15,851.18$ & $69,895.10$ \\
\hline \multicolumn{2}{|l|}{ Cost of therapy in int. group plus $20 \%$ of initial increase } & $22,825.87$ & $90,071.26$ \\
\hline \multicolumn{4}{|l|}{ Increase in cost of therapy in usual care cohort } \\
\hline \multicolumn{2}{|c|}{ by $50 \%$ of increase in int. group during intervention year } & $14,134.61$ & $62,991.55$ \\
\hline \multicolumn{2}{|c|}{ by $50 \%$ of increase in int. group in the year after intervention } & $14,834.73$ & $65,348.96$ \\
\hline \multicolumn{2}{|c|}{ by $50 \%$ of increase in int. group five years after intervention } & $17,663.38$ & $75,192.31$ \\
\hline \multirow[t]{2}{*}{ All health states costs } & plus $20 \%$ & $18,208.91$ & $80,886.70$ \\
\hline & minus $20 \%$ & $20,839.19$ & $83,637.15$ \\
\hline \multirow[t]{2}{*}{ Cost of AMI } & plus $20 \%$ & $19,018.94$ & $81,803.59$ \\
\hline & minus $20 \%$ & $20,029.16$ & $82,720.10$ \\
\hline \multirow[t]{2}{*}{ Cost of CHD death } & plus $20 \%$ & $19,128.91$ & $82,412.23$ \\
\hline & minus $20 \%$ & $19,918.90$ & $83,027.97$ \\
\hline \multirow[t]{2}{*}{ Cost of angina first year } & plus $20 \%$ & $19,418.90$ & $82,094.90$ \\
\hline & minus $20 \%$ & $19,628.91$ & $82,428.79$ \\
\hline \multirow[t]{2}{*}{ Cost of subsequent years } & plus $20 \%$ & $19,213.87$ & $81,819.61$ \\
\hline & minus $20 \%$ & $19,833.94$ & $82,704.08$ \\
\hline Cost of Ml subsequent year & plus $20 \%$ & $19,411.71$ & $75,321.84$ \\
\hline \multirow[t]{2}{*}{ Utilities of health states } & plus $10 \%$ & $24,936.50$ & $119,105.45$ \\
\hline & minus $10 \%$ & $16,041.93$ & $62,827.15$ \\
\hline \multicolumn{2}{|l|}{ Constant utility by age } & $15,704.95$ & $66,144.66$ \\
\hline Constant utilities by age and utility of health states & plus $10 \%$ & $20,056.55$ & $95,748.04$ \\
\hline Constant utility by age and utilities of health states & minus $10 \%$ & $12,904.99$ & $50,523.74$ \\
\hline \multicolumn{2}{|l|}{ Utility by age using Polish-specific utility values $[19,20]$} & $18,502.18$ & $78,082.36$ \\
\hline \multicolumn{4}{|l|}{ Duration of the effect } \\
\hline \multicolumn{2}{|l|}{ Effect of the intervention lasts 15 years } & $8,880.86$ & $40,978.86$ \\
\hline \multicolumn{2}{|l|}{ Effect of the intervention lasts five years } & $66,596.69$ & $25,3117.7$ \\
\hline \multicolumn{4}{|l|}{ Effectiveness of the intervention } \\
\hline Effectiveness as in the whole EUROACTION project & & $16,251.78$ & $45,636.14$ \\
\hline Distribution through primary events & & & \\
\hline Proportion of AMI increases by $50 \%$ & & $19,452.87$ & $81,017.28$ \\
\hline Proportion of CHD deaths increases by $50 \%$ & & $16,698.04$ & $72,379.78$ \\
\hline Starting age of participants \pm 5 years & & & \\
\hline Age & 52 & $22,982.79$ & $95,161.01$ \\
\hline & 62 & $14,919.37$ & $61,128.78$ \\
\hline
\end{tabular}

SBP — systolic blood pressure; TC — total cholesterol; HDL-C — high density lipoprotein cholesterol; PLN — New Polish zloty (2010 values); ICER — incremental cost per quality-adjusted life years (QALY); AMI — acute myocardial infarction; MI — myocardial infarction; CHD — coronary heart disease; int. — intervention 
exact duration of the EUROACTION effect is uncertain and could be established only by a longer prospective study. As Poland belongs to the group of European countries with high $\mathrm{CHD}$ risk, in this analysis it was assumed that the Framingham risk equations would predict the absolute CHD risk in Polish people reasonably well. However, Poland-specific validation is necessary to decrease the uncertainty about the accuracy of these predictions. The ability of the Framingham equations to capture a real value of the intervention as they include some, but not all, risk factors addressed by the EUROACTION intervention is a separate problem. The distribution data to primary events, transition probabilities of secondary events and utility weights were taken from published literature, which introduced additional uncertainty into the model. Poland-specific data, particularly on utility weights of health states first and subsequent years after an event, would bring much more accuracy to the analysis; thus these results should be reassessed when this data becomes available.

On the other hand, the analysis was limited to CHD. Considering that the intervention on blood pressure could also have an effect on the incidence of cerebrovascular disease and that the intervention on smoking would have an effect on the incidence of lung cancer, it is likely that the inclusion of stroke, transient ischaemic attack and cancer in the analysis would yield to a further decrease in ICERs and that the EUROACTION model intervention would then be even more cost-effective. Polish patients in the study were of working age (mean 57 years) and it is likely that the inclusion of indirect costs could have a significant impact on the results and increase cost-effectiveness further.

In the present analysis, utility weights for the first year health states were taken from international studies, but Polish general utility values have also been published. For the latter, the authors stated several weaknesses of their study including small sample size and questionable representativeness of the sample $[19,20]$. Following this, Polish-specific values were used in the sensitivity analysis only. Also, the analysis was done from the health payer's perspective and did not include costs borne by patients and non-medical costs for society. Another limitation was related to the level of motivation of the participants. People willing to participate in trials are likely to be highly motivated, and extrapolating results to all people at high risk in Poland should be done with caution. The weakness of the study is the absence of registry data for Polish patients with CVD, which is why UK data was used. However, the study by Daly et al. [23] which compared treatment and clinical outcomes of patients with SA in Poland and the UK, based on data from the Euro Heart Survey on stable angina, revealed that for one year of the study follow-up there were no significant differences in clinical outcomes (non-fatal MI, acute coronary syndrome and fatal CHD event) between Polish and UK patients. A less important weakness of our analysis is that the laboratory prices used can only be considered as typical for Poland, but they do not fulfill the requirement for being regarded as fully representative as they were not randomly selected from the full list of laboratories in Poland.

It is obvious that the greater the risk is, the higher the cost-effectiveness of the preventive procedure. It would be interesting to know the threshold value for the risk parameters which defines cost-effectiveness. However, we are unable to address this in our paper, which focuses on the problem of whether small changes in risk factors which are the common effect of preventive interventions could be cost-effective at all.

\section{CONCLUSIONS}

The model, nurse-led, comprehensive CVD primary prevention programme developed in the EUROACTION project appears to be potentially highly cost-effective for high-risk male patients in Poland (below one GDP per capita per QALY). For women, the cost-effectiveness was lower, but still below the acceptable threshold (below three GDP per capita per QALY), although the sensitivity analysis showed that results were subject to some uncertainty.

\section{Acknowledgements}

EUROACTION was an international study carried out under the auspices of the European Society of Cardiology and funded by AstraZeneca through the provision of an unconditional educational grant to the European Society of Cardiology. The administrative organisation and list of participating investigators and other research personnel is published elsewhere [5].

\section{Conflict of interest: none declared}

\section{References}

1. World Health Organization, Regional Office for Europe, European health for all database, 2010.

2. Pachocki R, Banasiak W, Jaworski R. Cost of coronary artery disease (CAD) in Poland. 2008. [Poster presentation] International Society for Pharmacoeconomics and Outcomes Research (ISPOR) 11 ${ }^{\text {th }}$ Annual European Congress, November 8-11 2008, Athens, Greece.

3. Pająk A, Szafraniec K, Janion M et al.; for a POLCARD study group. The impact of the national Program of Cardiovascular Disease Prevention (PCVDP) on the quality of primary CVD prevention in clinical practice. Kardiol Pol, 2010; 68: 1332-1340.

4. Wood DA, Kotseva K, Jennings C et al. EUROACTION: a European Society of Cardiology demonstration project in preventive cardiology. Summary of design, methodology and outcomes. Eur Heart J Suppl, 2004; 6 (suppl. J): J3.

5. Wood DA, Kotseva K, Connolly S et al.; on behalf of EUROACTION Study Group. Nurse-coordinated multidisciplinary, family-based cardiovascular disease prevention programme (EUROACTION) for patients with coronary heart disease and asymptomatic individuals at high risk of cardiovascular disease: a paired, cluster-randomised controlled trial. Lancet, 2008; 371: 1999-2012.

6. Anderson KM, Odell PM, Wilson PWF et al. Cardiovascular disease risk profiles. Am Heart J, 1991; 121: 293-298.

7. Ward S, Lloyd Jones M, Pandor A et al. A systematic review and economic evaluation of statins for the prevention of coronary events. Health Technol Assess, 2007; 11: 1-160.

8. Central Statistical Office of Poland, branch yearbook. Demographic Yearbook of Poland 2009. Central Statistical Office, Warsaw 2009. 
9. Polonski L, Gąsior G, Gierlotka M et al. Polish Registry of Acute Coronary Syndromes (PL-ACS). Caracteristics, treatments and outcomes of patients with acute coronary syndromes in Poland. Kardiol Pol, 2007; 65: 861-872.

10. Zipes DP, Camm AJ, Borggrefe $M$ et al. ACC/AHA/ESC 2006 guidelines for management of patients with ventricular arrhythmias and the prevention of sudden cardiac death. Europace, 2006; 8: 746 .

11. Chmiel AL, Wierzbicka-Chmiel JD. Sudden cardiac death — an assessment of pre-hospital proceedings. Wiad Lek, 2007; 60: 396

12. Kind P, Dolan P, Gudex C et al. Variations in population health status: results from a United Kingdom national questionnaire survey. BMJ, 1998; 316: 736

13. Lacey EA, Walters SJ. Continuing inequality: gender and social class influences on self perceived health after a heart attack. J Epidemiol Commun Health, 2003; 57: 622.

14. Lenzen M. Scholte op Reimer W, Norekval TM et al. Pharmacological treatment and perceived health status during 1-year follow up in patients diagnosed with coronary artery disease, but ineligible for revascularization. Eur J Cardiovasc Nurs, 2006; 5: 115-121.

15. Ara R, Tumur I, Pandor A et al. Ezetimibe for the treatment of hypercholesterolaemia: a systematic review and economic evaluation. Health Technol Assess, 2008; 12: 1-232.

16. Latour-Perez J, de Miguel BE, Betegon L, Badia X. Using triple antiplatelet therapy in patients with non-ST elevation acute coronary syndrome managed invasively: a cost-effectiveness analysis. Value Health, 2008; 11: 853-861.

17. Pignone M, Earnshaw S, Tice JA et al. Aspirin, statins, or both drugs for the primary prevention of coronary heart disease events in men: a cost-utility analysis. Ann Intern Med, 2006; 144: 326-336.

18. Visser K, Kuntz KM, Donaldson MC et al. Pretreatment imaging workup for patients with intermittent claudication: a cost-effectiveness analysis. J Vasc Interv Radiol, 2003; 14: 53-62.

19. Golicki D, Niewada M, Jakubczyk M et al. Self-assessed health status in Poland: EQ-5D findings from the Polish valuation study. Pol Arch Med Wewn, 2010; 120: 276-281.

20. Golicki D, Jakubczyk M, Niewada M et al. Valuation of EQ-5D health states in Poland: first TTO-based social value set in Central and Eastern Europe. Value Health, 2010; 13: 289-297.

21. Wonderling D, Langham S, Buxton M et al. What can be concluded from the Oxcheck and British family heart studies: commentary on cost effectiveness analyses. BMJ, 1996; 312: 1274-1278.

22. Rasmussen SR, Thomsen JL, Kilsmark J et al. Preventive health screenings and health consultations in primary care increase life expectancy without increasing costs. Scand J Public Health, 2007; 35: 365-372.

23. Daly CA, Stepinska J, Deptuch T et al. Differences in presentation and management of Stable Angina from East to West in Europe: A comparison between Poland and the UK. Int J Cardiol, 2008; 125: $311-318$. 


\title{
Efektywność kosztowa programu pierwotnej prewencji chorób sercowo-naczyniowych w warunkach podstawowej opieki zdrowotnej. Wyniki polskiej części projektu EUROACTION
}

\author{
Nevena Šović1 ${ }^{1}$ Andrzej Pająk ${ }^{1}$, Piotr Jankowski², Alejandra Duenas³ ${ }^{3}$ Kalina Kawecka-Jaszcz² \\ Renata Wolfshaut-Wolak ${ }^{1}$, Urszula Stepaniak ${ }^{1}$, Paweł Kawalec ${ }^{1}$ \\ IInstytut Zdrowia Publicznego, Wydział Nauk o Zdrowiu, Uniwersytet Jagielloński, Collegium Medicum, Kraków \\ 2I Klinika Kardiologii i Nadciśnienia Tętniczego, Uniwersytet Jagielloński, Collegium Medicum, Kraków \\ ${ }^{3}$ IESEG School of Management (LEM-CNRS, HEMO), Paryż, Francja
}

\section{Streszczenie}

Wstęp: Prawidłowo zaplanowany program pierwotnej prewencji choroby niedokrwiennej serca (CVD) może istotnie obniżyć zachorowalność, jednak jego powszechne wdrożenie będzie miało znaczny wpływ na budżet opieki zdrowotnej i w związku z tym wymaga wcześniejszych analiz ekonomicznych.

Cel: Celem pracy było określenie kosztowej efektywności prowadzonego przez przeszkolone pielęgniarki kompleksowego programu pierwotnej prewencji CVD, który został opracowany i wdrożony w Polsce w ramach projektu EUROACTION u osób z wysokim ryzykiem sercowo-naczyniowym.

Metody: Koszty zastosowania programu pierwotnej prewencji CVD oceniono z wykorzystaniem modelu Markowa. W modelu przyjęto następujące stany zdrowia: wolny od choroby (wszystkie osoby na początku obserwacji), dławica piersiowa w pierwszym roku, ostry zawał serca, dławica piersiowa w następnym roku, zawał serca w następnym roku, zgon w wyniku CVD i zgon z pozostałych przyczyn. Korzyści zdrowotne związane z obniżeniem poziomu czynników ryzyka oceniono z zastosowaniem funkcji ryzyka wg Framingham Study, przyjmując częstość występowania zdefiniowanych stanów zdrowia wg rejestru w Wielkiej Brytanii. Horyzont czasowy analizy ustalono na 10 lat, a długość pojedynczego cyklu określono na 1 rok. Analiza została przygotowana z perspektywy płatnika. Przyjęto próg kosztowej efektywności na poziomie 3-krotnego produktu krajowego brutto (PKB) per capita. Przeprowadzono jednoczynnikową analizę wrażliwości. Wyniki zaprezentowano w postaci inkrementalnych współczynników kosztowej efektywności (ICER) przedstawiających koszt związany z uzyskaniem dodatkowego roku życia w pełnej jakości życia (QALY).

Wyniki: W polskiej części projektu EUROACTION stwierdzono, że największą korzyścią z programu pierwotnej prewencji było obniżenie o 14\% częstości palenia tytoniu i obniżenie o 7\% odsetka osób z wysokim ciśnieniem tętniczym w całej grupie. Wpływ na inne czynniki, w tym także stężenie lipidów osocza, był niewielki. Współczynniki ICER wynosiły 19524 PLN u mężczyzn i 82262 PLN u kobiet. U osób palących współczynniki ICER dla obu płci były niższe i wynosiły 12377 PLN u mężczyzn i 53471 PLN u kobiet. Wyniki były wrażliwe głównie na zmiany użyteczności przyjętych stanów zdrowotnych i zmiany wysokości niektórych kategorii kosztów, a także czasu trwania farmakoterapii.

Wnioski: U mężczyzn z wysokim ryzykiem prowadzony przez pielęgniarki kompleksowy program pierwotnej prewencji CVD (opracowany w ramach projektu EUROACTION) może być wysoce kosztowo efektywną procedurą. U kobiet osiągnięcie tych samych wyników jest bardziej kosztowne, ale również poniżej założonego progu opłacalności (3 PKB per capita). Modelowy kompleksowy program pierwotnej prewencji opracowany w projekcie EUROACTION jest potencjalnie wysoce efektywny kosztowo u mężczyzn z grupy wysokiego ryzyka w Polsce (< 1 PKB per capita na QALY). U kobiet efektywność kosztowa jest niższa, choć nadal poniżej akceptowalnego progu (3 PKB per capita na QALY), a także wyniki analizy są obarczone niepewnością, co wykazano w ramach analizy wrażliwości.

Słowa kluczowe: choroba niedokrwienna serca, pierwotna profilaktyka, projekt EUROACTION, efektywność kosztowa

Kardiol Pol 2013; 71, 7: 702-711

\section{Adres do korespondencji:}

dr n. med. Paweł Kawalec, Instytut Zdrowia Publicznego, Wydział Nauk o Zdrowiu, Uniwersytet Jagielloński, Collegium Medicum, ul. Grzegorzecka 20, 31-531 Kraków, e-mail: mxpkawal@cyf-kr.edu.pl

Praca wpłynęła: 24.05.2012 r. Zaakceptowana do druku: 19.03.2013 r. 